The publication included in this document should be referenced as follows:

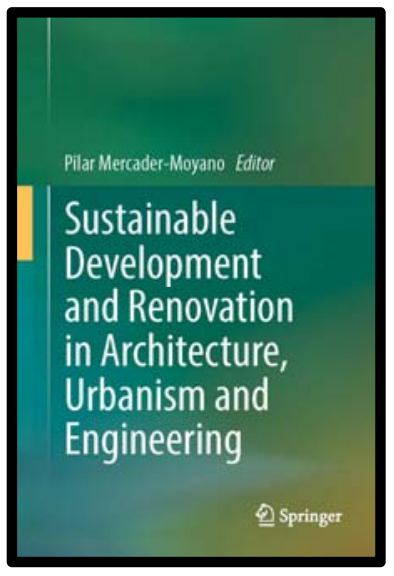

\title{
MARCH 2017
}

Social Rent Housing Refurbishment Demonstrator of LIFE Project "New4OId” (LIFE10 ENV/ES/439)

Emilia Román López, Gloria Gómez Muñoz \& Margarita de Luxán García de Diego

Included in:

Sustainable Development and Renovation in Architecture, Urbanism and Engineering

Publication details, including instructions for authors and subscription information: https://link.springer.com/book/10.1007/978-3-319-51442-0

\section{Please cite this document as:}

Román López, E., Gómez Muñoz, G., \& De Luxán García de Diego, M. (2017). Social Rent Housing Refurbishment Demonstrator of LIFE Project "New4Old" (LIFE10 ENV/ES/439). In P. Mercader-Moyano (Ed.), Sustainable Development and Renovation in Architecture, Urbanism and Engineering (pp. 203-214). Springer International Publising.

DOI: 10.1007/978-3-319-51442-0_17

To link to this document:

http://link.springer.com/chapter/10.1007/978-3-319-51442-0 17

The following document has been archived according to the publisher's default policies as a PRE-PRINT versión on the repository of the Universidad Politécnica de Madrid.

For more information, please visit:

http://www.sherpa.ac.uk/romeo/index.php?la=en\&flDnum=|\&mode=simple 


\title{
Social Rent Housing Refurbishment Demonstrator of LIFE Project "New4Old" (LIFE10 ENV / ES / 439)
}

\author{
${ }^{(1, *)}$ Román, Emilia, Gómez, Gloria ${ }^{(2)}$ and de Luxán, Margarita ${ }^{(3)}$
}

(1)(*) Ph.D. Architect cc60 Estudio de Arquitectura, Research group Sustainable Architecture and Urban Planning (GIAU+S).Universidad Politécnica de Madrid

(2) Ph.D. Architect cc60 Estudio de Arquitectura glogomu@cc60.com

(3) Ph. D. Architect Emerita Professor at the Upper Technical School of Architecture,

Uniiversidad Politécnica de Madrid

\begin{abstract}
This ecoefficient renovation of two buildings of social housing for rent is located in the historic center of Zaragoza and has been carried out among 2013 and 2015. It emerges from the conclusions and strategies developed for the NewSolutions4OldHousing project (LIFE10 ENV / ES / 439), funded by the European Commission. The general objective of LIFE project is to define the most appropriate methodology for the rehabilitation of social housing with criteria of energy and environmental sustainability and application of innovative technologies to combat climate change. The application of passive strategies in the refurbishment of these Demonstrator Buildings has helped to achieve thermal and lighting comfort with less energy-consumption, with savings above $70 \%$ in demand and about $25 \%$ in real consumption. These data are particularly relevant when the residents are renters with very limited incomes, vulnerable to problems such as energy poverty. Therefore, the proposed action serves to improve the passive behaviour of the building and to achieve greater thermal and lighting comfort and liability without increasing the financial costs related to energy consumption.
\end{abstract}

Palabras clave Refurbishment; Eco-Efficient; Climate change; Fuel poverty; Housing

\section{Introduction}

The aim of the intervention on the Demonstrator Buildings of the NewSolutions4OldHousing Project (LIFE10 ENV / ES / 439), co-funded by the European Commission, is to analyse the actual results after defining the most appropriate methodology and the best practices for the rehabilitation of social housing with

DOI: $10.1007 / 978-3-319-51442-0 \_17$

http://link.springer.com/chapter/10.1007/978-3-319-51442-0_17 
energy and environmental sustainability criteria. One of tasks performed has been the refurbishment of two buildings of social housing in Zaragoza, which act as a demonstrator in the project. In this way, it is possible to evaluate the measures implemented and the behaviour of buildings before and after the intervention. The institutions participating in the project are: the AITEMIN Technology Center, the Polytechnic University of Madrid (UPM), the Technology Centre of Ceramics and Glass of Portugal (CTCV) and the Municipal Zaragoza Housing Society (SMZV).

\section{Objetives}

The intervention on the two housing buildings has as specific objective to identify, apply and evaluate the most adequate project solutions to improve its energetic behaviour with regard to the climatic and social context in which they are placed and be able to measure the actual improvements resulting from it. The general objective of LIFE project is to define the appropriate methodology and best practices available for the renovation of social housing with criteria of energy and environmental sustainability, and also the application of innovative technologies to fight against climate change. Passive strategies in buildings are essential in social housing, especially when the tenants have very limited income.

\section{Methodology}

Regarding the Demonstrator Buildings, the main methodology is the analysis and comparison of diverse parameters of the construction states and results of their utilisation before and after the intervention.

There is no homogeneous corpus allowing to relate Demonstrators of the LIFE Programs in which antecedents can be established, neither specific states of the question that can be argued, since in the building field each case is unique finding itself in climatic, urban, constructive, technological, social even economic (concerning the money means to implement them); and even thematic as we are inside the Program that looks to care for diverse researches with very diverse Demonstrators.

The two buildings are located in the historic city of Zaragoza, the first of which (Building A) with access from the San Pablo St. 83-85 and the second (Building B) from the street Basilio Boggiero. Between the two buildings there is an inner courtyard. The buildings have, respectively, 18 and 12 homes for social rent. This represents a user profile with low incomes. Therefore, the working method to define improvement measures for the building, has paid special attention to the cur- 
rent conditions of use of housing and the possibilities of incorporating passive strategies to improve indoor comfort without increasing consumer costs. Thus situations of fuel poverty (Sanchez Guevara, 2016) are avoided. Being rented dwellings, users are changing over time and therefore have chosen self-regulating solutions that do not require successive neighbors have to learn some management.

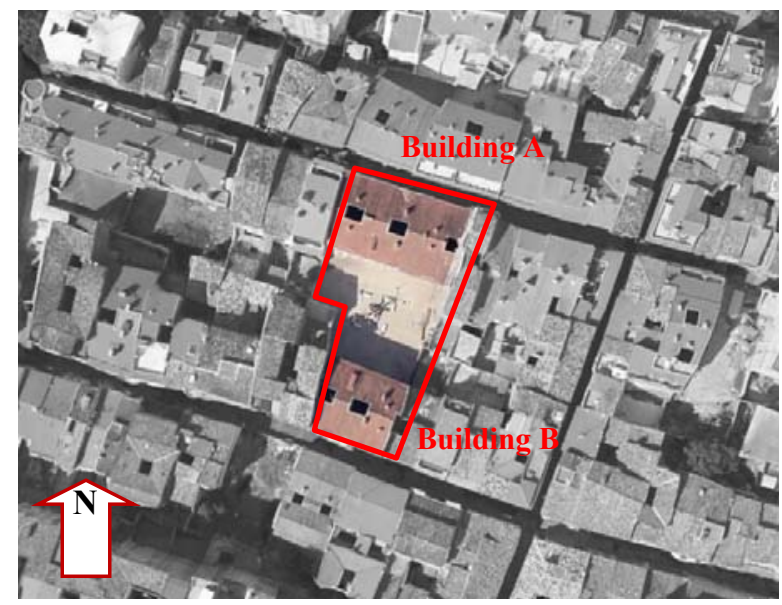

Fig. 1 Location of buildings

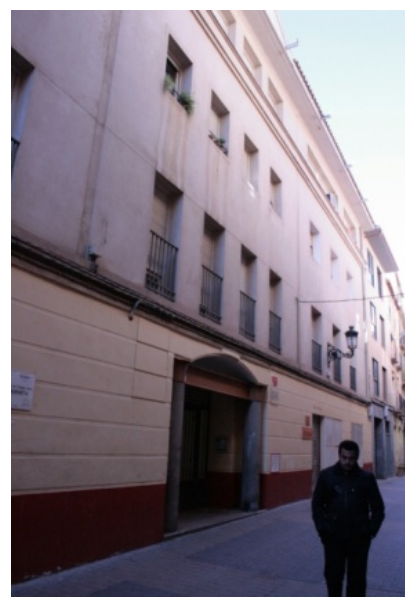

Fig. 2 North facade of the building in San Pablo St.

For defining the solutions to implement in refurbishment, we analyzed the climatic and urban aspects of the area. A survey user to know their perception and their needs regarding comfort conditions of housing has been done. Monitoring the building before and after the performance has allowed evaluate the effectiveness and impact of the measures taken. An important starting data for the selection of solutions is that the contract budget was limited to 358,000 euros.

\section{Initial conditions analysis}

The buildings are owned by Municipal Zaragoza Housing Society (SMZV) and are located in one of the areas identified as vulnerable (Hernández Aja et al, 2016). They were built in the early 90s and are two blocks between medians with two façades oriented north and south. They have several inner courtyards of $3 \times 4$ meters. Each building has three floors, in addition to ground floor. On each floor they are located up to 6 homes distributed in two staircases. The houses are oriented to the north or south and many of its rooms open onto interior courtyards. On the ground floor there is an access from the street, the stairs and the courtyard, and local occupied by neighborhood associations. The roof of the building is inclined gable, on a partitioned chamber currently has no ventilation. 


\subsection{Climate analysis and influence of climate change}

Zaragoza has a continental mediterranean climate with warm summers. The average temperature of the maximum is around $21^{\circ} \mathrm{C}$ and average minimum near $10^{\circ} \mathrm{C}$. In the winter months, the average minimum temperatures may be $5^{\circ} \mathrm{C}$ and in summer the average maximum measurements can reach $30^{\circ} \mathrm{C}$. The relative humidity varies between $50 \%$ and $80 \%$. The most frequent winds in winter correspond to the direction NW to SE and summer. The first winds are cold character and the second, warm..

Actions carried out with energy and environmental sustainability criteria, that want to get long-term results, should consider the effect of climate change. In the case of the refurbishment, the impact of these changes can be significant if the forecasts made for Spain (Olcina Cantos, 2009) are met. According to this forecast, the summer conditions for inland cities, such as Zaragoza, will be modified by rising temperatures and reduced rainfall. Both issues, especially the first, involve changes in energy exchanges with the outside of the building and therefore its comfort conditions.

Bioclimatic comfort studies performed indicate that in the relatively near term, the number of days it will be needed to consider strategies summer, increases progressively. In the case of buildings, by refurbishment on existing buildings, it is necessary consider the progressive increase in average temperatures, especially in summer. This implies that although heating energy consumption will be reduced, the energy associated to cooling, if passive measures are not implemented, will increase.

In addition to the phenomenon of climate change, interventions in the urban context should consider heat island (Cuadrat Prats, Vicente-Serrano, Sánchez \& Saz, 2005). Studies indicate again the importance of considering adaptation strategies to temperature conditions, since both the expected evolution of the climate and the phenomenon of heat island, they are longer necessary and will be of greater significance even in future.

\subsection{Urban contexts}

After analysing the climate and identify interest in raising passive measures on buildings, it is necessary a solar study of the buildings and the constraints due its urban situation. Both buildings are oriented north-south. During the cold months the southern facade, which overlooks the central courtyard in the case of building $\mathrm{A}$, is guaranteed to receive four hours of sunlight (10:00 am-14: $00 \mathrm{~h})$ even in the 
month of January is the colder. This is due to the dimensions of the central courtyard and building height faced within the same plot in the north. Only the ground floor receives fewer hours of radiation. Aimed at San Pablo St., the north facade of this building would always be in shadow. The south facade of the building B, which is accessed from the street Boggiero, behaves like north facade in the cold months because urban arrangement prevents solar radiation reaches you, while in summer, is exposed to sunlight. The southern courtyards facades receive little direct radiation; only in the upper part.

During the colder months, the central courtyard is in shadow for much of the day. Only in the hottest hours of the months of October and February could receive radiation a small part of it, on the south facade (approx. 1/3 of its surface). The possibilities of natural ventilation are reduced due to the orientation and the high density of the urban fabric, but are allayed by the size, orientation and shape of the inner courtyard of apple and the chimney effect of the inner courtyards.

\subsection{Users characterization}

After conducting surveys to users of the building, it follows that there are differences in the feeling of comfort among people living in dwellings oriented north and those living in the south oriented. In many of them, especially in the northoriented, there is a problem of heating in the winter months. In the summer months overheating seen in all homes to south. In general, users consider getting warmer in winter and cooler in summer are the most important measures to achieve comfort. A significant finding is that $43 \%$ of users do not use the heating homes because they can not afford it, being an important indicator of the fuel poverty of some neighbours.

The above said makes that the mix of the energetic expenses does not match the usual average: thermal conditioning expenses are reduced, hence increasing the percentages of lighting and water heating.

\section{Measures for energy refurbishment of buildings}

Following the completion of studies together with some previous articles (Luxán, Vazquez Gomez, Roman, Barbero, 2009) and considering the budget for the work; in the project have been prioritized the following improvement measures in buildings after comparing and calibrating different possibilities. 


\subsection{Improved of thermal envelope}

Is improved the thermal performance of building envelope to reduce energy demand. The buildings were built according to the Basic Conditions Thermal regulation CT-79, applicable at the time of the drafting of the initial project. The original building exceeds those requirements because the building had a heating electric wire radiant and this implied an improvement of the transmittances of these elements, required by the power company at the time of contracting the service. For reduction in energy demand has implemented the following.

Table 1 Measures to improve the thermal envelope of buildings A and B

\begin{tabular}{l|c|c|c|c}
\hline Edificio & Element & Mesure of improve & Before Value & After value \\
\hline $\begin{array}{l}\text { Building } \\
\text { A y north } \\
\text { facades } \\
\text { and } \\
\text { courtyards } \\
\text { in } \\
\text { building B }\end{array}$ & Walls & $\begin{array}{c}\text { External thermal } \\
\text { insulation composite } \\
\text { system } \\
\text { cm expanded } \\
\text { polystyrene }\end{array}$ & $0,50 \mathrm{~W} / \mathrm{m}^{2}{ }^{\circ} \mathrm{K}$ & $0,27 \mathrm{~W} / \mathrm{m}^{2}{ }^{\circ} \mathrm{K}$ \\
$\begin{array}{l}\text { Building } \\
\text { A }\end{array}$ & Windows & $\begin{array}{c}\text { Replacing glass } \\
\text { maintaining existing } \\
\text { woodworks }\end{array}$ & $3,17 \mathrm{~W} /\left(\mathrm{m}^{2} \cdot \mathrm{K}\right)$ & $1,6 \mathrm{~W} /\left(\mathrm{m}^{2} \cdot \mathrm{K}\right)$ \\
\hline $\begin{array}{l}\text { Buildings } \\
\text { A y B }\end{array}$ & Roof & $\begin{array}{c}\text { Incorporation } 12 \mathrm{~cm} \\
\text { fiberglass cover. } \\
\text { Improved ventilation }\end{array}$ & $1,18 \mathrm{~W} / \mathrm{m}^{2}{ }^{\circ} \mathrm{K}$ & $0,17 \mathrm{~W} / \mathrm{m}^{2}{ }^{\circ} \mathrm{K}$. \\
\hline $\begin{array}{l}\text { Buildings } \\
\text { A y B }\end{array}$ & Floor & $\begin{array}{c}\text { Incorporation of } 5 \mathrm{~cm} \\
\text { fiberglass ceiling on } \\
\text { outdoor spaces }\end{array}$ & $1,16 \mathrm{~W} / \mathrm{m}^{2}{ }^{\circ} \mathrm{K}$ & $0,43 \mathrm{~W} / \mathrm{m}^{2}{ }^{\circ} \mathrm{K}$. \\
\hline
\end{tabular}

\subsection{Hybrid solar system for hot water and electricity}

The houses have an electric boiler to produce hot water. For budgetary reasons only it has built a solar system for hot water production in building A, which reduces energy consumption of the building. The installed solar panels are hybrids and are used for hot water production and for power generation for public areas and recharging points for electric car in basement.

\subsection{Environmental indoor courtyard conditioning}

The courtyard between the two buildings serves as open for the use of residents and design of housing space. Before the refurbishment, it was characterized by the lack of shade. It has installed a pergola that acts as a sunscreen, which will mini- 
mize overheating soil and air in the warm months, and have relocated existing banks in areas of the most comfortable patio. The incorporation of vegetation boxes will be useful to raise the relative humidity.

\subsection{Sunscreen in south facade}

Slats has been installed on the south facade of the building A Fig- 3 and 4 for exterior shading. Thus comfort conditions are improved inside the building in the summer months avoiding direct solar radiation on this side of the envelope subject to the biggest yearly variation in its conditions . It is a horizontal fixed sunscreen inclined slats, located on the bottom lines of the windows of each plant and continuously throughout the south facade of the building A. It has been designed to give shade to the windows and façade as well during the summer months and become minimal during the cold months without action from the users.

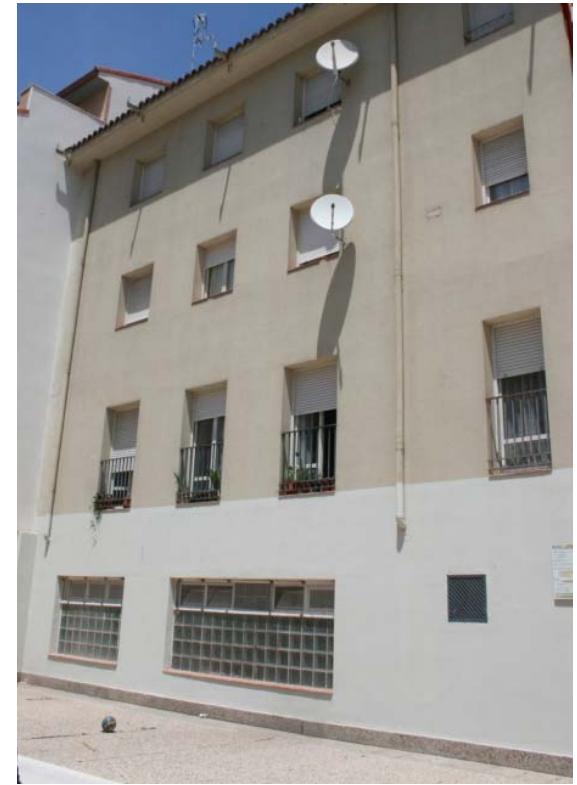

Fig. 3 South facade before renovation. October noon

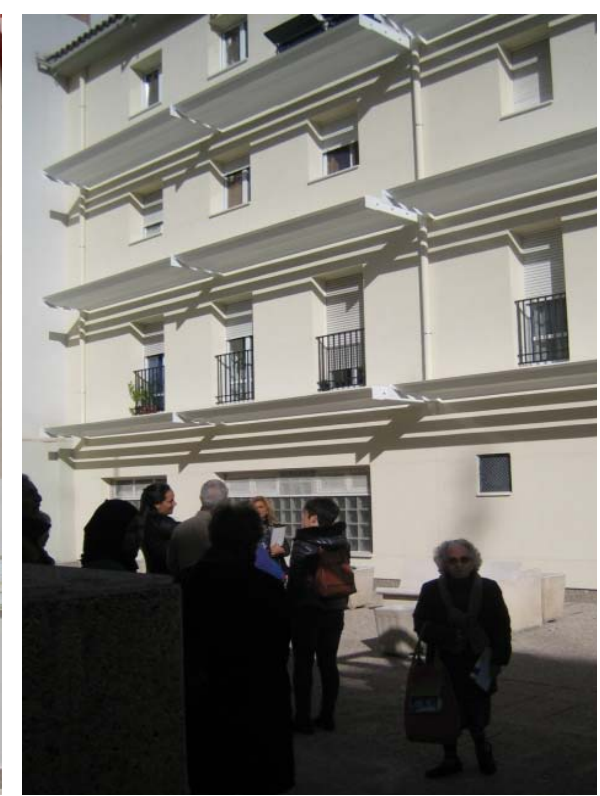

Fig. 4 South facade after renovation. December morrning 


\subsection{Improving natural lighting in yards}

This is one of the innovative solutions of this Demonstrator. As aforesaid, the percentage of electric consumption grows on the total as it is practically indispensable. To achieve energy savings in the building lighting, light ducts of the Solatube type, but redesigned to exterior-exterior use, have been incorporated in the courtyards of the building A for natural lighting and for energy savings in lighting the building.

This measure is important because the three courtyards of the building A have a dimension of $3.00 \times 4.00$ meters and $70 \%$ of the rooms in housing and common areas get light through these patios. The ducts have been dimensioned to allow natural light to get into the rooms at least 2 meters from the patio

Measured in Spring 2016, the lighting in the lower plant of the courtyard was 600 lux without the duct effect (shutting the upper side captor) and 1.100 lux with the light duct in operation, what makes artificial lighting unnecessary most of the day for the rooms opening to these courtyards

It has been installed motion detectors in common areas of the building illuminated by night from the hybrid panels' energy.
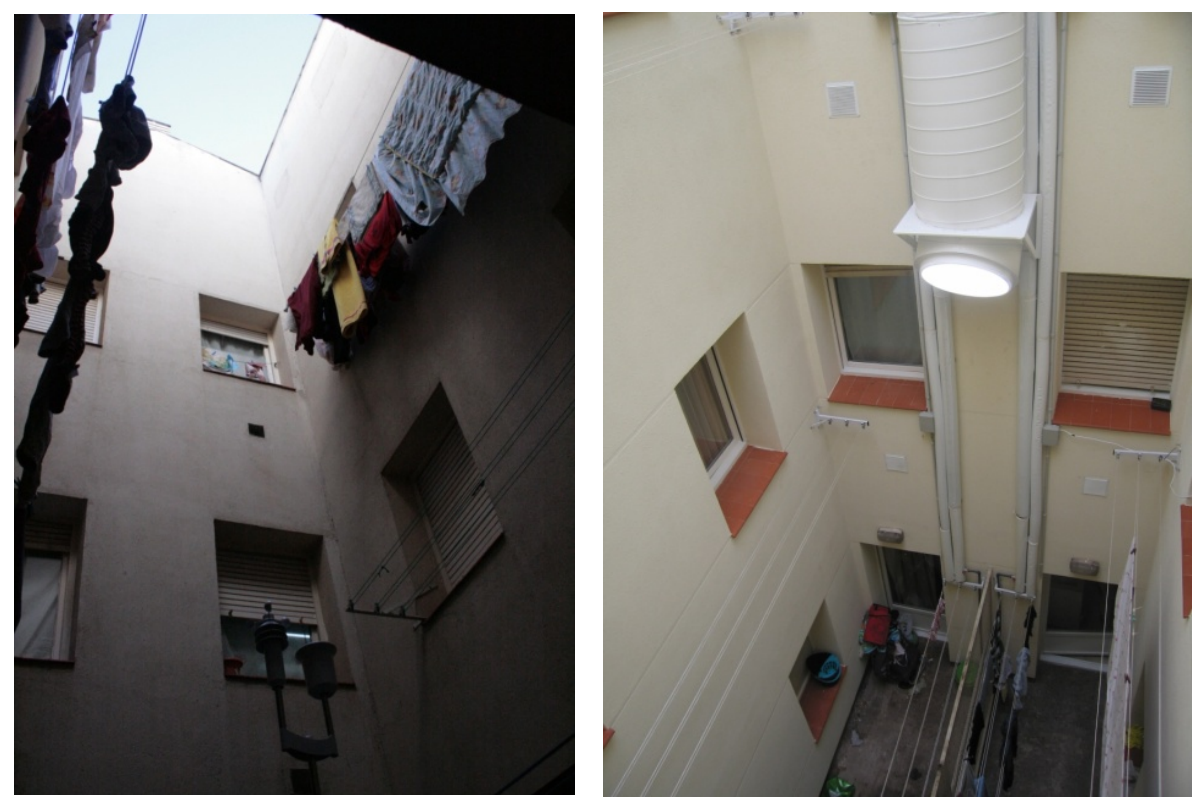
Fig. 5 Courtyard before refurbishment

Fig. 6 Courtyard after refurbishment

\section{Monitoring results}

Monitoring of housing has been made by the team of the Polytechnic University of Madrid. The works of this energy rehabilitation of residential building were completed in November 2014. The monitoring was conducted homes since 2013, before the intervention in buildings, until the end of 2015, completion date of the project LIFE. This has allowed us to obtain and quantify the impact of interventions and to draw conclusions for the project objectives. The main monitoring data obtained were as follows.

According to data provided by the team, it has achieved a reduction of $71.42 \%$ in energy demand and $25.50 \%$ in the average real consumption. They were reduced by $76.32 \% \mathrm{CO}_{2}$ emissions.

Whereas the neighbours had previously made use of heating, it has been estimated household savings of $985 €$ / year. This implies a ratio of investment / savings: $6.5 \mathrm{kWh} / \mathrm{y}$ reduction in energy demand per euro invested and an estimated return on investment of 12 years.

In the case of the demonstrator project, reducing overall energy demand is estimated at $266,000 \mathrm{kWh} /$ year, reducing $\mathrm{CO}_{2}$ emissions by $61,400 \mathrm{~kg} /$ year and economic savings $29,550 € /$ year for all 30 families benefit.

Natural lighting in the inner courtyards has raised the level of light at the lower floors from 600 lux to 1.100 lux, what makes the rooms opening to them not needing artificial light most of the day.

There has also been tracking production and waste during construction, resulting in a reduced consumption of resources required for the manufacture of construction materials by 180 tons, 18.48 and 68.37 tep tons of $\mathrm{CO}_{2}$ emissions per household rehabilitated. For every inhabited housing they have reduced construction waste and demolition of 170 tons. 


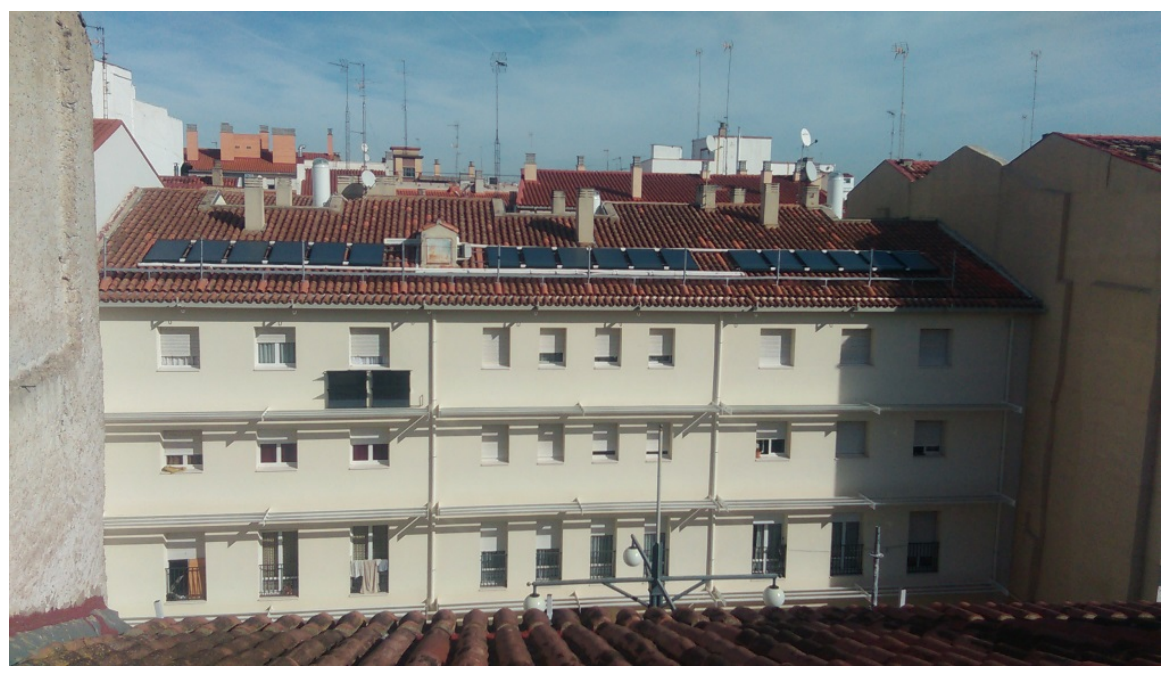

Fig. 7 Building A after intervention facade insulation, incorporation of sunscreen, hybrid solar panels for hot water and electricity, solar lighting conduits for patios and prototype passive solar heating.

\section{Conclusions}

The study of initial conditions residential building in Zaragoza and climate, urban, social and economic context has helped define a series of measures for energy refurbishment according to the characteristics and needs of its users. These measures seek to achieve greater thermal comfort for residents without increasing the economic cost of consumption, since they are people with low incomes, at risk of fuel poverty.

For this reason, the intervention in these two buildings has improved its passive behaviour, avoiding complex systems with high maintenance costs. Only by working in the building envelope, improving isolation and sunscreen hollow south, reducing energy demand it has reached more than $70 \%$ compared to the previous state.

As seen, passive strategies are very important when social housing rehabilitated, especially where social rental scheme where tenants live with very limited income. In that sense, the intervention on the building envelope is more durable and less costly to maintain and outlays for the user that the change of conditioning systems in homes and therefore more appropriate in situations like this. 
The participation of residents in the building phase characterization has revealed the high percentage of users who can not use regular air conditioning systems for economic reasons. Hence the relevance of this work, which aims to propose actions adapted to urban, climatic and social conditions of these buildings.

\section{Citation and References}

Cuadrat Prats, J. M., Vicente-Serrano, S. M., \& Saz Sánchez, M. A. (2005). Los efectos de la urbanización en el clima de Zaragoza (España): La isla de calor y sus factores condicionantes. Boletín de la A.G.E., 311-327.

Hernández Aja, A., Vázquez Espí, M., García Madruga, C., Matesanz Parellada, Á., Moreno García, E., Alguacil Gómez, J. y Camacho Gutiérrez, J. 2011. Análisis urbanístico de Barrios Vulnerables. [en línea]. Madrid. Disponible en: http://habitat.aq.upm.es/bbvv/bbvv.html.

Luxán, M., Vázquez, M., Gómez, G., Román, E., Barbero, M. (2009) Actuaciones con criterios de sostenibilidad en la rehabilitación de viviendas en el centro de Madrid. EMVS. ISBN 978-84-935719-8-6 50-65, 98-106

Sánchez Guevara, C (2016) Propuesta metodológica de evaluación de la pobreza energética en España. Indicadores para la rehabilitación de vivienda. Tesis doctoral. Universidad Politécnica de Madrid

Olcina Cantos, J. (2009). Cambio climático y riesgos climáticos en España. Investigaciones Geográficas (49), 197-220.

\section{Acknowledgments}

The authors wish to thank Roberto Diaz (AITEMIN) the project coordination and the Municipal Zaragoza Housing Society the collaboration in the project, especially to Juan Rubio, Fernando Albiac, Paloma Bozman and Margarita Garcia. 